\title{
The neurology behind three wounded French artists during the great world war
}

\author{
A neurologia por trás de três artistas franceses feridos durante a grande guerra mundial \\ Bruno Kusznir VITTURI', Wilson Luiz SANVITO'
}

\begin{abstract}
A unique association joins Guillaume Apollinaire, Blaise Cendrars and Louis Ferdinand Céline. Besides being great exponents of French literature, they were all neurologically wounded during the First World War. Apollinaire had a traumatic brain injury, Cendrars developed phantom limb neuropathic pain and Céline presented radial nerve paralysis. There is quite an evidence that supports that their artistic output was also influenced by acquired neurological conditions during the war. The examples of these three French authors reveal the surprising intimacy Neurology can share with art and history.
\end{abstract}

Keywords: art; history of neurology; traumatic brain injury; World War I; peripheral neuropathy.

RESUMO

Uma associação única une Guillaume Apollinaire, Blaise Cendrars e Louis Ferdinand Céline. Além de serem grandes expoentes da literatura francesa, todos eles foram feridos neurologicamente durante a Primeira Guerra Mundial. Apollinaire sofreu traumatismo cranioencefálico, Cendrars desenvolveu dor neuropática do membro fantasma e Céline apresentou paralisia do nervo radial. Há bastantes evidências que sustentam que a sua produção artística também foi influenciada pelas condições neurológicas adquiridas durante a guerra. Os exemplos desses três autores franceses revelam a surpreendente intimidade que a neurologia pode compartilhar com a arte e a história.

Palavras-chave: arte; história da neurologia; lesões encefálicas traumáticas; primeira guerra mundial; neuropatia periférica.

A unique association joins Guillaume Apollinaire, Blaise Cendrars and Louis Ferdinand Céline. All of them were French, played a crucial role in literature in Paris and were neurologically injured in world wars. Surprisingly, they also changed their artistic production due to acquired neurological conditions.

\section{GUILLAUME APOLLINAIRE (1880-1918)}

Guillaume Apollinaire is considered one of the most important literary figures of the early twentieth century. Apollinaire was born in Rome but by the age of eighteen, he had settled in Paris. In 1914 he joined the French army, volunteering to defend his adopted country in World War I. In spite of goodwill, a sad event would ironically mark his life and career. Apollinaire was hit with a shrapnel fragment in the right temporal region just after receiving the acceptance of his naturalization (Figure 1). Fortunately, trauma was rather superficial and required only minor interventions. After 2 weeks, he presented progressive headaches, balance problems, and fatigue. An episode of loss of consciousness followed by left hemiplegia made him undergo neurosurgery which probably revealed a chronic subdural hematoma ${ }^{1}$.

After discharge, the sequels were not obvious, but in the eyes of close friends like Andre Breton, Apollinaire was not the same. His personality changed and his emotions were unstable. The joyful, extraverted, witty Apollinaire seemed to have been replaced by someone sad, embittered, angry and distrustful. The author of Le Pont Mirabeau became emotionally indifferent and with marked affective flattening. Apollinaire himself was aware that his brain had changed"1,2: "I am not anymore who I was, in any way, and if I listened to myself, I would now become a priest of a religious person". Perhaps the most dramatic change in his behavior involved his relationship with Madeleine: while he had written passionate letters to her

\footnotetext{
${ }^{1}$ Faculdade de Ciências Médicas da Santa Casa de São Paulo, Departamento de Neurologia, São Paulo SP, Brazil.

Bruno Kusznir VITTURI (iD) https://orcid.org/0000-0002-2821-9042

Correspondence: Bruno Kusznir Vitturi; Santa Casa de São Paulo School of Medical Sciences; Rua Dr. Cesário Motta Júnior, $112 ; 01221-020$ São Paulo SP, Brazil; E-mail:z_azul@hotmail.com

Conflict of interest: There is no conflict of interest to declare.

Received on July 3, 2019; Received in its final form on September 6, 2019; Accepted on September 23, 2019.
} 


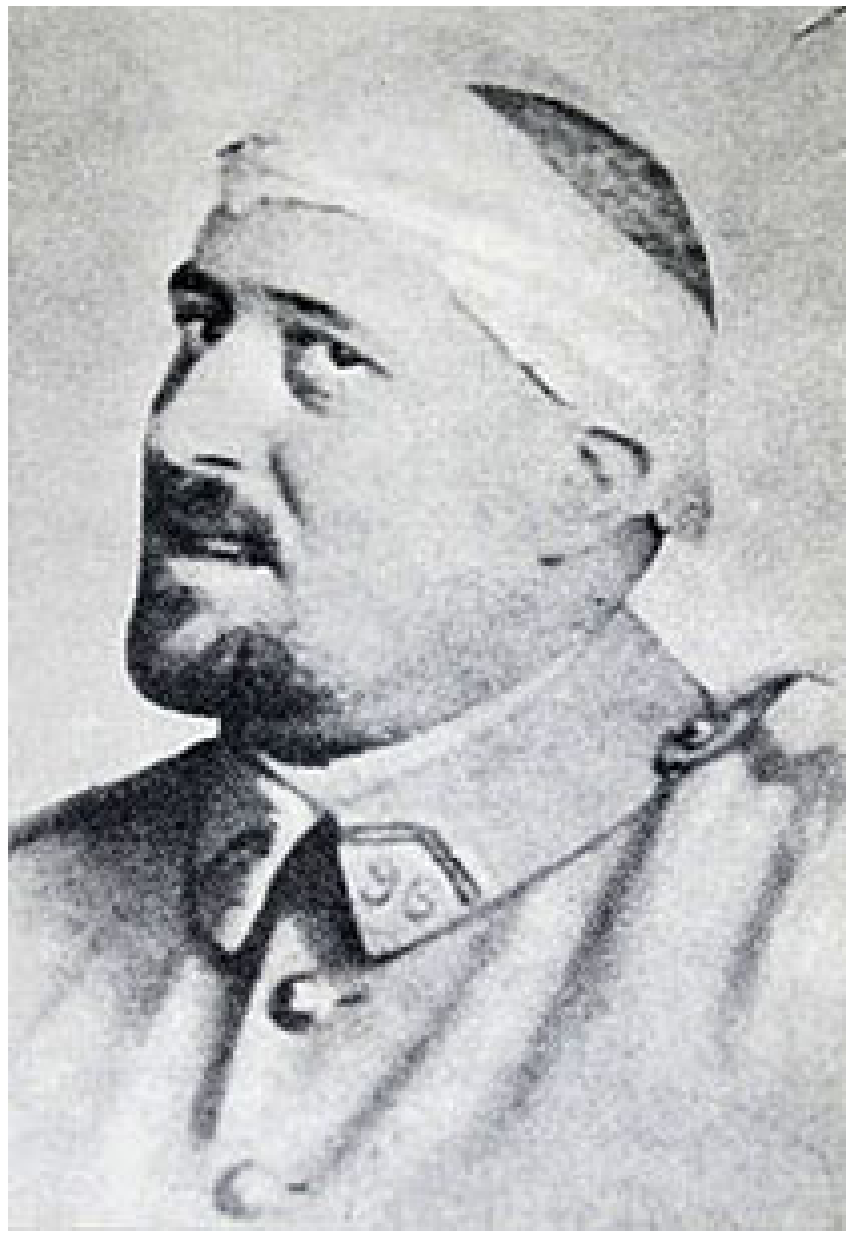

Source: Wikimedia Commons.

Figure 1. Guillaume Apollinaire in 1916 with head bandaged after traumatism.

before the wound, after the trauma he wrote short, nonemotional notes asking her not to visit him anymore ${ }^{1,2}$. This fascinating change in the life of the French poet would give rise to the eponym 'Apollinaire syndrome' to designate neurobehavioral changes with preserved cognition and no other neurological dysfunction after right lateral temporal lobe damage ${ }^{2}$.

Apollinaire's artistic output did not show less poetic quality from poems written before the war. Nevertheless, some specialists argue that Apollinaire's creativity was influenced somehow by brain damage. After the trauma, he painted several watercolors depicting personal scenes, still lives, war activities, and poetic topics ${ }^{3}$. This shift towards a new form of artistic creativity has already been reported in certain cases of neurological disorders occurring in artists ${ }^{4,5}$.

\section{BLAISE CENDRARS (1887-1961)}

Frédéric Sauser, who used the pseudonym Blaise Cendrars, was born in Switzerland and settled definitively in France before World War I, where he gained prominence in the European modernist movement. At the beginning of the war, he registered the Légion étrangere and soon he became

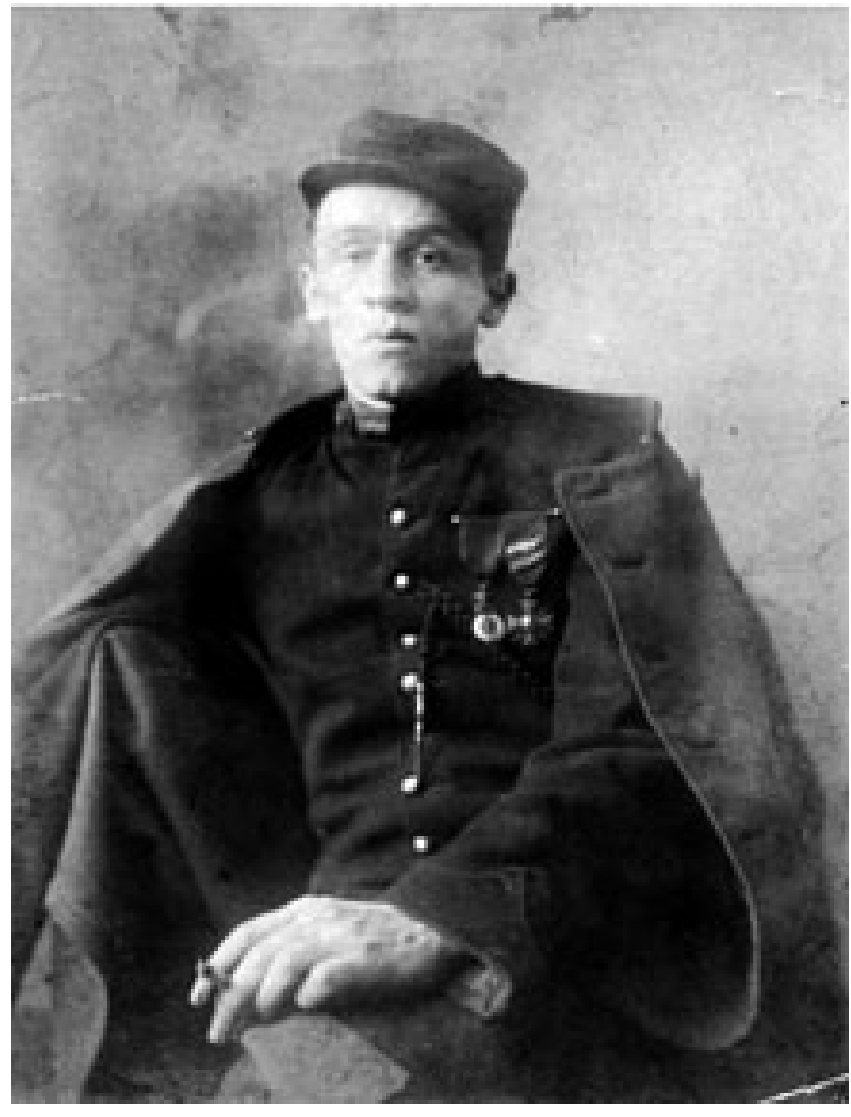

Source: Swiss Literary Archives, Berne.

Figure 2. Blaise Cendrars in 1916 after his amputation.

a French citizen as well as Apollinaire. In 1915, during a conflict in Champagne, Cendrars was shot in the right forearm and doctors decided to amputate the limb $^{6}$ (Figure 2). From that moment, the author of Prose du Transsibérien would be tormented "day and night" by a severe stump pain all his life. At that time, he compared his bandaged missing limb to a "big baby' or a 'foreign thing'. A painful phantom arm could not be better described by him: 'A phantom can be seen but does not exist, while a phantom limb exists but cannot be seen.' Cendrars compared the pain as a sharp needle or a knife being introduced into his flesh. Curiously, in his pre-war texts, Cendrars had made several allusions to missing hands and amputations, which later would sound like a premonition ${ }^{1,6}$.

If the impact on his artistic production is difficult to be measured, for Cendrars, the phantom hand indeed had mutated poetry into a phantom. After the amputation, Frédéric dramatically stopped writing poetry and began a new career as a novelist ${ }^{7}$. Interestingly, after his wound, Cendrars would write one of his most famous fictional stories, La main coupée, which was published twenty years later. While he had been perhaps the most revolutionary of the pre-war avant-garde poets, his new style and image after the war completely changed his image as a writer, both in the public and among other writers. His interest in poetry left him together with his right limb ${ }^{3,6}$. 


\section{LOUIS FERDINAND CÉLINE (1894-1961)}

Louis-Ferdinand Destouches, whose pen name was Louis Ferdinand Céline, is one of the most famous French-speaking writers of the twentieth century. He developed a personal style of writing that changed French literature. Céline was enlisted in a cavalry regiment in 1912 and fought for France in the Great War. In 1914, while he was out of a trench to transmit an order to an infantry colonel, he was severely wounded by a bullet in the right arm leading to radial nerve paralysis. Céline also started to complain of hyperesthesia in the radial nerve sensitive territory: "The bullet shattered the bone on 4 to 5 centimeters. However, the nerves have been painfully affected". Neurosurgery was indicated but no further improvement was observed. Céline needed electrical treatment to stimulate the recovery of his right radial nerve. In 1939, a medical report confirmed the persistence of neuropathy and would grant him an invalidity pension: "Radial paralysis. Long intervention scar on the dorsal side of the arm. Paralyzed extensors. Dropping hand. Severe pain reactions in the sensitive radial nerve territory triggered by hand movements" 8 .

It is reasonable to speculate that war and neurological damage could have influenced Céline's work. He used his personal experience with electrotherapy to write Voyage au bout de la nuit. In the novel, the war hero Bardamu received electric therapy: "That, Bardamu, is how I mean to treat my patients, electricity for the body, [...]!". After the war, Céline's personal history in the World War also become part of his texts, including many descriptions of "war neurosis" and shell-shocked soldiers ${ }^{9}$.

The examples of Guillaume Apollinaire, Blaise Cendrars and Louis-Ferdinand Céline reveal the surprising (and fascinating) intimacy Neurology can share with art and history.

\section{References}

1. Bogousslavsky J, Tatu L. Neurological impact of World War I on the Artistic Avant-Garde: The examples of André Breton, Guillaume Apollinaire, and Blaise Cendrars. In: Tatu L, Bogousslavsky J (editors). War Neurology. Front Neurol Neurosci. 2016;38:155-67. https://doi. org/10.1159/000442654

2. Bogousslavsky J. The lost love of Gui and Madeleine. Emotional syndrome and right temporal behavior of Guillaume Apollinaire. Rev Neurol (Paris). 2003 Feb;159(2):171-9. MDOI-RN-02-2003-159-20035-3787-101019-ART4 [pii]

3. Maingon C, Tatu L. Creative Minds in the Aftermath of the Great War: Four Neurologically Wounded Artists. In: Bogousslavsky J, Tatu L (editors). Neurological Disorders in Famous Artists - Part 4. Front Neurol Neurosci. 2018;43:37-46. https://doi.org/10.1159/000490403

4. Vitturi BK, Sanvito WL. HISTORICAL NOTE Maurice Ravel's dementia: the silence of a genius A demência de Maurice Ravel: o silêncio de um gênio. Arq Neuropsiquiatr. 2019:77(2):136-8. https://doi. org/10.1590/0004-282X20180134
5. Vitturi BK, Sanvito WL. What do Flaubert, Dostoevsky and Machado de Assis have in common with neurology? Arq Neuropsiquiatr. 2017 Dec;75(12):892-4. https://doi.org/10.1590/0004-282×20170145

6. Tatu L. The missing hands of Blaise Cendrars. In: Bogousslavsky J, Hennerici MG, Bäzner H, Bassetti C (editors). Neurological Disorders in Famous Artists - Part 3. 2010;27:143-59. https://doi. org/10.1159/000311198

7. Tatu L, Bogousslavsky J. The medical itineraries of Blaise Cendrars. Neuropsychiatry marks life and literature. Rev Neurol (Paris). 2017;173(3):125-30. https://doi.org/10.1016/j.neurol.2017.02.010

8. Tatu L, Roynette O, Bogousslavsky J. Louis-Ferdinand Céline: From First World War Neurological Wound to Mythomania. Front Neurol Neurosci. 2018;43:23-36. https://doi.org/10.1159/000490401

9. Bogousslavsky J, Tatu L. Writers as Shell Shock Witnesses during World War I. Bogousslavsky J, Tatu L (editors). Neurological Disorders in Famous Artists - Part 4. Front Neurol Neurosci. 2018;43:47-58. https://doi.org/10.1159/000490404 